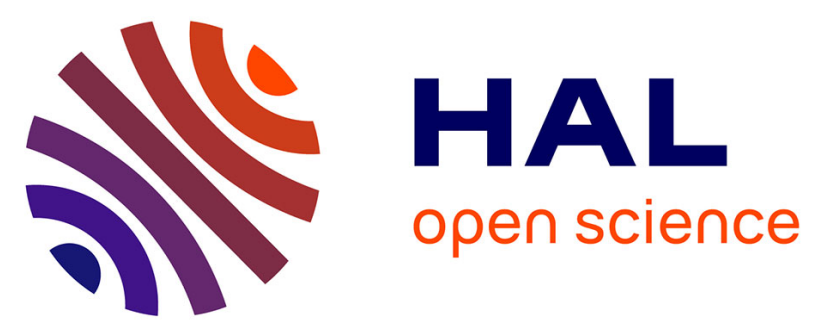

\title{
Vitellogenin synthesis in cultured hepatocytes, an in vitro test for the estrogenic potency of chemicals
}

\author{
Catherine Pelissero, G. Flouriot, Jean-Luc Foucher, B. Bennetau, J.
}

Dunogues, Florence Le Gac, J.P. Sumpter

\section{- To cite this version:}

Catherine Pelissero, G. Flouriot, Jean-Luc Foucher, B. Bennetau, J. Dunogues, et al.. Vitellogenin synthesis in cultured hepatocytes, an in vitro test for the estrogenic potency of chemicals. Journal of Steroid Biochemistry and Molecular Biology, 1993, 44, pp.263-272. 10.1016/0960-0760(93)90086-C . hal-02715919

\section{HAL Id: hal-02715919 \\ https://hal.inrae.fr/hal-02715919}

Submitted on 1 Jun 2020

HAL is a multi-disciplinary open access archive for the deposit and dissemination of scientific research documents, whether they are published or not. The documents may come from teaching and research institutions in France or abroad, or from public or private research centers.
L'archive ouverte pluridisciplinaire HAL, est destinée au dépôt et à la diffusion de documents scientifiques de niveau recherche, publiés ou non, émanant des établissements d'enseignement et de recherche français ou étrangers, des laboratoires publics ou privés. 


\title{
VITELLOGENIN SYNTHESIS IN CULTURED HEPATOCYTES; AN IN VITRO TEST FOR THE ESTROGENIC POTENCY OF CHEMICALS
}

\author{
C. Pelissero, ${ }^{1 *}$ G. Flouriot, ${ }^{2}$ J. L. Foucher, ${ }^{3}$ B. Bennetau, ${ }^{4}$ J. Dunoguiss, ${ }^{4}$ F. Le Gac ${ }^{3}$ \\ and J. P. SUMPTER ${ }^{1}$
}

'Department of Biology and Biochemistry, Brunel University, Uxbridge, Middlesex UB8 3PH, England, ${ }^{2}$ Laboratoire de Biologie Moléculaire Université de Rennes I, Campus de Beaulieu, 35042 Rennes Cedex France, ${ }^{3}$ Laboratoire INRA de Physiologie des Poissons, Campus de Rennes Beaulieu, 35042 Rennes Cedex France and 'Laboratoire de Chimie Organique et Organométallique, URA 35 CNRS, Université de Bordeaux I, 351, Cours de la Libération, 33405 Talence Cedex France

(Received 28 July 1992; accepted 9 November 1992)

\begin{abstract}
Summary - We describe here an in vitro technique to assess the estrogenic activity of chemicals. This technique is based on rainbow trout hepatocytes incubated in a basic medium free of any additional growth factors or estrogenic chemicals and uses the production of vitellogenin (VTG) as a marker for the estrogenic potency of the compounds tested. The system allows at least some of the metabolic transformations which are undertaken by the liver cells in vivo and could therefore be used for xenobiotic compounds which exhibit estrogenic activities after liver metabolic transformation. A dose-response curve was always consistently obtained using estradiol-17 $\left(E_{2}\right)$, with a mid point at around $100 \mathrm{nM} \mathrm{E}_{2}$ and a maximum response at around $1000 \mathrm{nM}$. Established estrogens such as $17 a 1$ ethynylestradiol $\left(\mathrm{EE}_{2}\right)$ or diethylstilboestrol (DES) were also tested. $\mathrm{EE}_{2}$ appeared to be equipotent with $\mathrm{E}_{2}$ and DES slightly less potent. $E_{2}$ conjugates were, perhaps surprisingly, also very potent. Estradiol-3-sulfate was equipotent with $E_{2}$ and estradiol-17 $\beta$-glucuronide approx. $10 \%$ as potent. Other steroids such as androgens and progesterone, though active in the bioassay, were 3 orders of magnitude less potent than $\mathrm{E}_{2}$. Of the various steroids tested, only cortisol, at concentrations up to $50 \mu \mathrm{M}$, was completely inactive. Six different phytoestrogens were tested in the assay. All were weakly estrogenic, possessing approximately one thousanth the potency of $E_{2}$ (they were as potent as the androgens and progesterone). All six phytoestrogens, as well as the androgens and progesterone, were tested in the presence of tamoxifen. In all cases tamoxifen reduced the production of VTG significantly, demonstrating that the estrogenic action of all of these compounds was most likely mediated by the $\mathrm{E}_{2}$ receptor. The potencies determined here may not reflect the situation in vivo but can provide complementary results about the activity of chemicals which need an hepatic metabolization to be estrogenic. Hepatocyte cultures would profitably be developed in other species to sustain these results.
\end{abstract}

\section{INTRODUCTION}

Estrogenic compounds are widely spread in the environment $[1,2]$ and their actions on animal and plant physiology are complex. They have been defined by Hertz using this assessment: "the primary effect of an estrogen is the stimulation of mitotic activity in the tissues of the female genital tract. A substance which can directly elicit this response is an estrogen, one that cannot is not."[3]. This definition was given in an attempt to simplify the classification of chemicals and to comply with the results

*To whom correspondence should be addressed at his present address: Laboratoire d'Océanographie Biologique, Université de Bordeaux I, Avenue des Facultés, 33405 Talence Cédex, France. obtained using relatively simple in vitro tests. However this definition, implicating $a$ direct action, is likely not to be appropriate in vivo for the following reasons: in reality, estrogenic xenobiotic compounds originate from different sources like food [4], water [2] or soil [5] and, according to their nature, the routes they follow can include more than one metabolic transformation $[2,6,7]$. Consequently, the demonstration of a direct effect, or a lack of effect in vitro, on uterus or mammary tissue is no longer relevant. Indeed, some of the metabolic transformations can either increase or decrease the estrogenic potency of a defined chemical [8]. The structure-activity relationships of various estrogenic compounds have received some attention [9-11], but no exhaustive rules have yet been defined 
which can be used to explain the estrogenic potency of a particular compound. Up to now the only sure way to determine the estrogenic potency of a chemical is to test it in a biological system [12-14]. This is generally done by comparison to a reference compound.

Since in vivo tests are subject to large interindividual variations according to sex, age or physiological status of the tested animals, they require large numbers of individuals to overcome this inherent variability. Because of this, in vitro tests have often been prefered $[15,16]$, since they usually combine both sensitivity and reliability and use only a small number of animals, if any. However, most of the metabolic steps which normally occur in vivo are absent in vitro and thus the results obtained in this kind of system have to be considered cautiously and must never be directly extrapolated to the in vivo situation. If an in vitro system could be developed in which at least some of the metabolic transformations which occur naturally in vivo could be maintained, it could be used to provide interesting complementary results for the determination of the estrogenic potency of chemicals on a define target organ. This paper presents such a test, which is based on the ability of primary cultures of healthy liver cells of trout to respond to estrogenic stimulations by producing vitellogenin (VTG) [17]. The originality of this system is based to the fact that liver cells even in vitro are able to maintain several enzymatic activites as demonstrated in various models including hepatocytes of rat and fish [18-21]. However, because of the variation of the hepatic metabolism according to species, sex and age $[22,23]$, the results reported apply only to the particular system being used. However, such a system will nevertheless give complementary information about the potency of chemicals which usually need an hepatic transformation to induce an estrogenic response and thus will not directly appear estrogenic (i.e. in receptor binding tests or tests on cells collected from other organs like uterus or mammary tissue).

VTG is a large, complex protein synthesized by hepatocytes of oviparous (egg laying) vertebrates [24]. After secretion into the blood, it is sequestered by the oocytes and stored as yolk, to subsequently provide a food supply for the developing embryo[25]. In vertebrates, VTG synthesis is generally considered to be dependant on stimulation of the liver by estrogens [primarily estradiol-17 $\beta\left(\mathrm{E}_{2}\right)$ in vivo] [see 26 for a review] though in fact we are not aware of any study that has examined comprehensively the specificity of the response. We have used hepatocytes from rainbow trout, one of the commonest of farmed fish worldwide, to investigate whether VTG synthesis is indeed only an estrogen-dependent phenomenon and if so, whether it could form the basis of a new bioassay for estrogens.

\section{EXPERIMENTAL}

\section{Fish}

The fish used in this study were rainbow trout (Oncorhynchus mykiss) collected from a local fish farm (Iver, Middlesex, England) and were either males, immature females or sterile. Their average weight was about $500 \mathrm{~g}$. Each doseresponse curve has been obtained at least twice if not three times on hepatocytes collected from male or female fish. When fish of different sexes were tested in replicate cultures we did not observe significantly different dose-response curves from one sex to another. However, all the results presented in this paper were obtained using hepatocytes from immature females.

\section{Reagents}

All the chemicals used here were purchased from Sigma (Dorset, England) unless otherwise stated. The medium was Dulbeco's Modified Eagle's Medium (DMEM), $20 \mathrm{mM}$ Hepes buffered at 7.8 before sterilization by filtration. This medium was 'phenol red-free'. It contained the following antibiotics: $2500 \mathrm{U}$ penicillin/l, $2.5 \mathrm{mg}$ streptomycine $/ 1,6.25 \mu \mathrm{g}$ amphotericine B/l $2.5 \mathrm{mg}$ kanamycine/ 1 and $1 \mathrm{mg}$ fungizone/l, the last antibiotic from Gibco (Middlesex, England). Collagenase from Clostridium histolyticum (quality $\mathrm{H}$ ) was purchased from Boeringher Mannheim (Sussex, England)

\section{Compounds tested}

The phytoestrogens tested were synthesized according to Pelissero et al. [27]. The steroids tested were either USP standards or Sigma standards. The $E_{2}$ analogs diethylstilboestrol (DES) and ethynylestradiol $\left(\mathrm{EE}_{2}\right)$ were purchased from Sigma.

\section{Liver perfusion}

The fish were killed by a blow on the head, wiped with a tissue saturated with alcohol and immediately placed in a laminar flow hood where the following operations were performed. $5000 \mathrm{U}$ Heparin was injected into the heart 
immediately after the body cavity was opened. The liver was then perfused $(10 \mathrm{ml} / \mathrm{min})$ for $20 \mathrm{~min}$ through the intestinal artery with $150 \mathrm{mM} \mathrm{NaCl}$, Hepes buffered solution ( $10 \mathrm{mM}, \mathrm{pH} 7.8$ before filtration) containing $3 \mathrm{mM}$ of $\mathrm{KCl}$ and $0.5 \mathrm{mM} \mathrm{Na}_{2} \mathrm{HPO}_{4}$. Simultaneously the heart was cut into two pieces to avoid excess pressure in the blood system. When all the blood had been removed from the liver, a $130 \mathrm{mM} \mathrm{NaCl}$, Hepes buffered solution (10 mM, pH 7.8 before filtration) containing $3 \mathrm{mM}$ of $\mathrm{KCl}, 0.5 \mathrm{mM} \mathrm{Na}_{2} \mathrm{PO}_{4}, 13 \mathrm{mM} \mathrm{Ca} \mathrm{Cl}$ and $260 \mathrm{mg}$ of collagenase $/ 1$ was perfused for $30 \mathrm{~min}$.

\section{Preparation of the cells}

Once perfused for $30 \mathrm{~min}$, the liver was dissected out and placed in a sterile Petri dish in $20 \mathrm{ml}$ of medium (DMEM). There it was torn into small pieces, each one being shaken gently to disperse the cells. The cell suspension was filtered through three layers of a commercial sterile pad and centrifuged at $30 \mathrm{~g}$ for $1 \mathrm{~min}$ at room temperature. This last operation was repeated until the supernatant was clear. A concentrated cell suspension was prepared that was tested for its viability using Trypan blue. Finally a suspension of $10^{6}$ viable cells $/ \mathrm{ml}$ was prepared in the medium.

\section{Cell culture}

The cells were distributed into $30 \mathrm{~mm}$ dia wells $\left(3 \times 10^{6}\right.$ cells/well) and shaken gently on an orbital shaker throughout the entire culture. The speed of the orbital shaker was adjusted so that a circular motion was produced in each of the wells. This led to the cells clumping together into aggregates in the centre of the well. $2 \mathrm{ml}$ of the medium were removed every second day and replaced by the same amount of fresh medium, until the cell aggregates were regular in shape and of an average size of $150 \mu \mathrm{m}$ dia (this step takes between 4 and 6 days). Once the aggregation was completed, the cells were stimulated by the addition of an appropriate amount of hormone dissolved in $100 \mu 1$ medium along with $1.9 \mathrm{ml}$ of fresh medium at each change of the medium. Usually, the compounds tested (steroids or phytoestrogens) were not highly soluble in water. Therefore, they were dissolved in ethanol or in DMSO, making sure that the concentration of these organic solvents was constant in all the stimulating solutions and never exceeded $0.3 \%$ in the wells. The $\mathrm{pH}$ was measured in the old medium collected at each change of medium and was found to range between 7.5 and 7.4 .

\section{Vitellogenin assay}

VTG concentrations in the medium were determined as described previously $[28,29]$. No VTG was detectable in the absence of $E_{2}$ in the medium. This was true whether hepatocytes from male or immature female were used; if however, hepatocytes from a maturing female were used, there was a rather high "basal" level of VTG in the wells after 2 days of culture, although this level fell rapidly (within 10 days) to an undetectable value (results not shown).

\section{Statistical analysis}

Statistical analyses were performed to compare the potency of $E_{2}$ to that of $E_{2}$, DES and estradiol-17 $\beta$-glucuronide ( $E_{2} g l u c$ ). The sigmoidal curves were first linearized: $x=\log$ (concentration) and $y=\arcsin (2 p-1)$, where $p$ was the percentage of VTG induced by the compound tested compared to the highest value obtained with $E_{2}$. The following regression equations were obtained:

$$
\begin{array}{lr}
\mathrm{E}_{2}: & y=-115.80+48.606 x \\
& R^{2}=0.965 \quad(n=7) \\
\mathrm{EE}_{2}: & y=-113.52+48.199 x \\
& R^{2}=0.972 \quad(n=7) \\
\text { DES: } \quad y=-153.16+44.000 x & R^{2}=0.965 \quad(n=5) \\
\mathrm{E}_{2} \text { Gluc: } \quad y= & -155.93+38.616 x \\
& R^{2}=1.000 \quad(n=4)
\end{array}
$$

The slopes of the regression lines were then compared using a covariance analysis. Since no statistical differences were noted, the potencies of the various compounds were assessed by using four concentrations of each compound able to induce four different levels of VTG $(100$; $200 ; 300$ and $400 \mathrm{ng} / \mathrm{ml})$. These concentrations were then compared to those of $E_{2}$ able to induce the same responses. The means of these values are given $\pm \mathrm{SD}$. No calculation was performed with estradiol-3-sulfate $\left(\mathrm{E}_{2} \mathrm{SO}_{4}\right)$, since the shape of the dose-response curve obtained could not be linearized properly using the linearization formula adopted for all the other compounds. The values obtained in the experiment using tamoxifen were the means of triplicates and were compared using a non-parametric test according to [30]. 


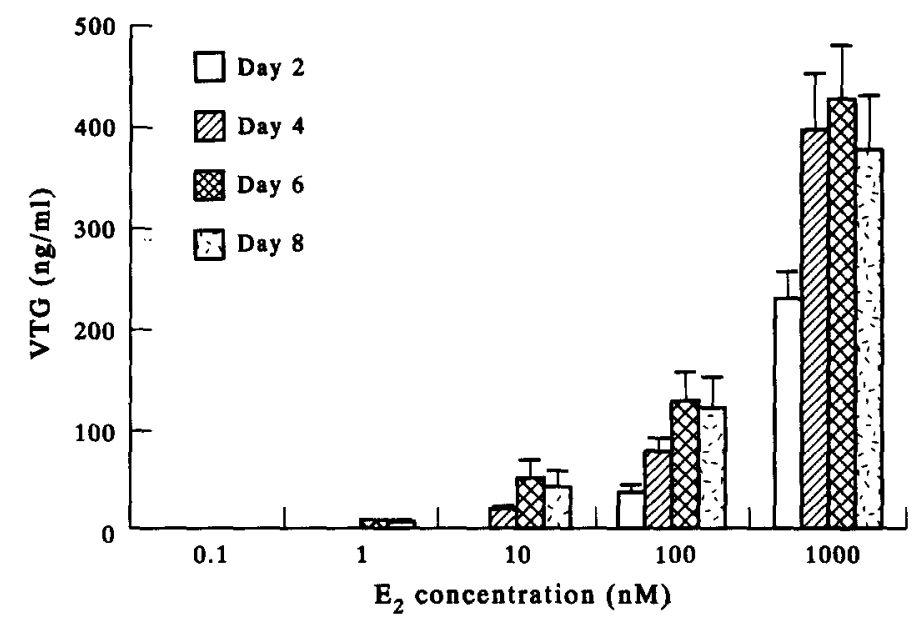

Fig. 1. VTG production in hepatocyte culture after $2,4,6$ or 8 days of exposure to different doses of $E_{2}$ $(1,10,100$ and $1000 \mathrm{nM})$. Each value is given as a mean of triplicates and bars are standard deviations. The control value is $4 \mathrm{ng} / \mathrm{ml}$.

\section{RESULTS}

Figure 1 presents the results obtained in an experiment which assessed the production of VTG in the presence of various doses of $E_{2}$ after $2,4,6$ or 8 days of stimulation. In each case, the medium was changed every second day and therefore the VTG synthesized by the hepatocytes was allowed to accumulate in the medium for the same 2 day period. This figure shows that the best response was obtained after 6 days of stimulation since the production obtained between 6 and 8 days of stimulation, was not statistically different from that obtained between 4 and 6 days. We therefore decided to stimulate the cells for 6 days before assaying the medium to assess the response.

A clear sigmoid dose-response curve was obtained when hepatocytes were stimulated with various doses of $E_{2}$ (Fig. 2). The minimum concentration required to induce a significant response was around $10 \mathrm{nM}(1 \mathrm{nM}$ sometimes produced a measurable response) and a maximum response occured around $1000 \mathrm{nM}$. However, some variability of the sensitivity of the hepatocytes was observed from one culture to another and therefore the results obtained using different compounds had to be compared with a dose-response curve to $E_{2}$ obtained in the same experiment. We do not know what mechanism was responsible for this variation in sensitivity and studies are underway at the moment in our laboratory to try to understand this phenomenon. Figure 2 also presents the results obtained for various steroids including androgens, progesterone and cortisol. Both androgens and progesterone induced VTG secretion, and had a potency approx. 1000 times less than that of $E_{2}$. A similar result was obtained using $17 \alpha, 20 \beta(\mathrm{OH})_{2}$ progesterone (results not shown). Cortisol was the only compound tested not to induce VTG synthesis.

Figure 3 shows the results obtained in cultures stimulated with testosterone, 11ketotestosterone and progesterone employed at $10 \mu \mathrm{M}$ either alone or simultaneously with $1 \mu \mathrm{M}$ of tamoxifen. The response in a nonstimulated control and a control stimulated by $10 \mathrm{nM} \mathrm{E}_{2}$ are also shown. This figure shows that, in all cases, the level of VTG production induced by the steroid was significantly decreased by tamoxifen. For androgens and progesterone, addition of tamoxifen led to the total inhibition of VTG production, since the results obtained with tamoxifen were not significantly different from the control. In the case of

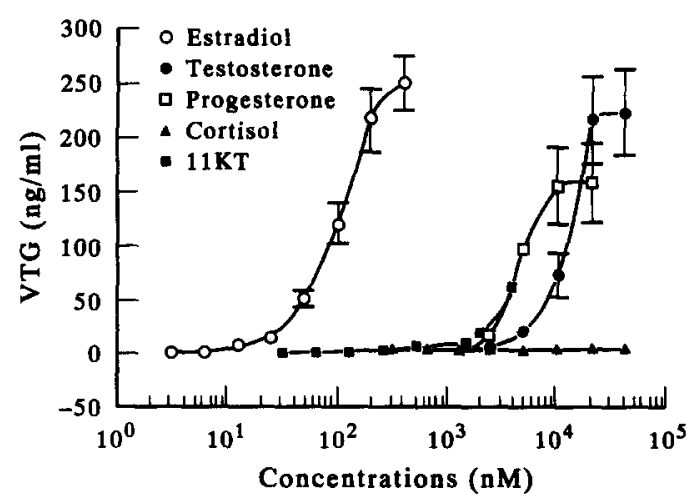

Fig. 2. Stimulation of hepatocytes in culture by increasing doses of $E_{2}$, testosterone, 11-ketotestosterone, progesterone and cortisol. All compounds are pure USP reference standards or standards from Sigma. The values are means of triplicates and bars are standard deviations. The control value is $0.5 \mathrm{ng} / \mathrm{ml}$. 


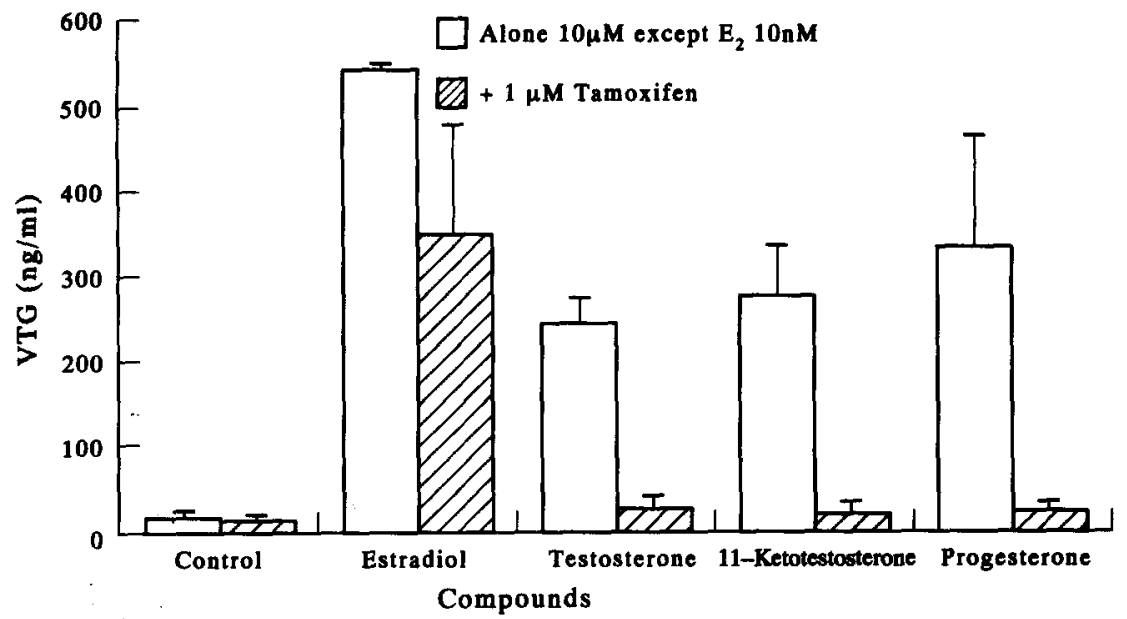

Fig. 3. Effect of tamoxifen $(1 \mu \mathrm{M})$ on the production of VTG by rainbow trout cultured hepatocytes stimulated by androgens (testosterone, 11-ketotestosterone) and progesterone (all at $10 \mu \mathrm{M}$ ). $\mathrm{E}_{2}$ was used at $10 \mathrm{nM}$. The results are means of three values $\pm \mathrm{SD}$. In all cases (except control) tamoxifen significantly decreased the production of VTG $(P<0.01)$ according to a non-parametric analysis. The control value is $2.3 \mathrm{ng} / \mathrm{ml}$.

$\mathrm{E}_{2}$, the presence of tamoxifen significantly decreased the production of VTG, but it was still significantly higher than the control

Figure 4 shows that the $\mathrm{E}_{2}$ conjugates $\mathrm{E}_{2} \mathrm{SO}_{4}$ and $E_{2}$ gluc both induced VTG secretion. $E_{2}$ gluc appeared to have an estrogenic potency $40 \pm 15$ times less than that of $\mathrm{E}_{2}$, whereas $\mathrm{E}_{2} \mathrm{SO}_{4}$ exhibited an estrogenic activity comparable to that of $E_{2}$. These results were confirmed using different preparations of both $\mathrm{E}_{2} \mathrm{SO}_{4}$ and $\mathrm{E}_{2}$ gluc.

Sigmoidal dose-response curves were obtained with $\mathrm{EE}_{2}$ and DES; their activity is given in comparison to that of $E_{2}$ in Fig. 5. The potency of $\mathrm{EE}_{2}$ was similar or slightly higher than that of $E_{2}(1.15 \pm 0.05$ times more estrogenic than $E_{2}$ ) whereas DES was $14 \pm 4$ times less potent than $E_{2}$.

Finally, using this bioassay we determined the estrogenic activity of some of the isoflavonoid

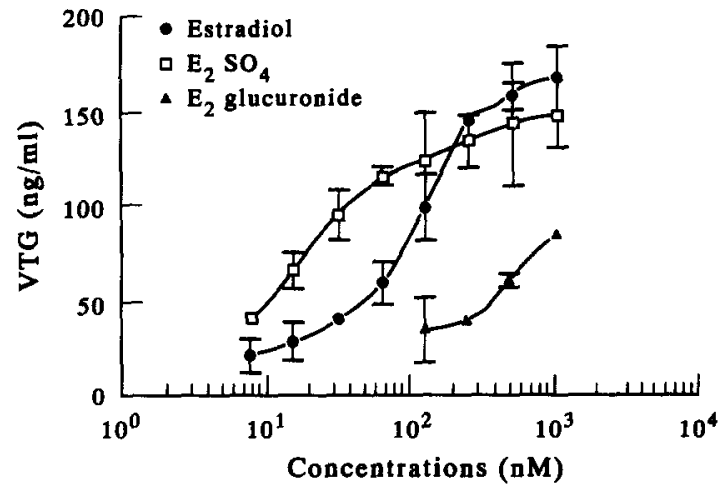

Fig. 4. Stimulation of hepatocytes in culture by increasing doses of $\mathrm{E}_{2}, \mathrm{E}_{2} \mathrm{SO}_{4}$ and $\mathrm{E}_{2}$ gluc. The values are means of triplicates and bars are standard deviations. Control value is $1.2 \mathrm{ng} / \mathrm{ml}$. compounds known as phytoestrogens. The results obtained are presented in Figs 6 and 7. All six phytoestrogens were active; all had a similar potency, being around 1000 -to 2000 -fold less active than $E_{2}$. Figure 8 shows the effect of tamoxifen on the induction of VTG synthesis by phytoestrogens in the culture system. The activity of all six phytoestrogens was significantly inhibited by tamoxifen. In all cases, except in that of genistein, tamoxifen completely blocked the production of VTG which was not significantly different from the control.

\section{DISCUSSION}

Hepatocyte cultures, especially of mammalian origin, have and continue to be used for a wide variety of toxicological studies and the metabolic activity of these cells in culture is both

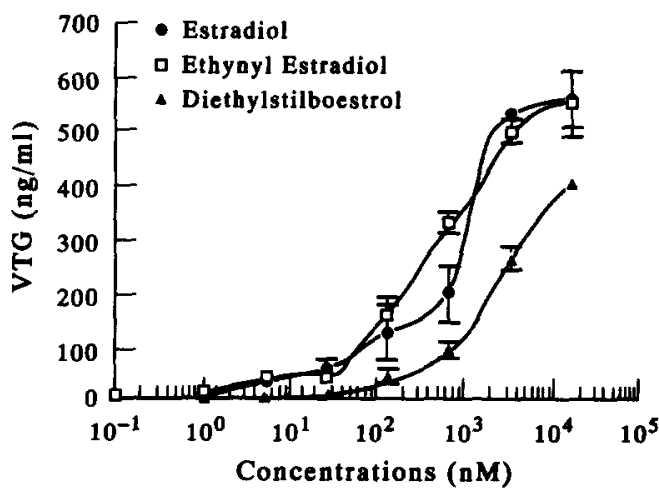

Fig. 5. Stimulation of hepatocytes in culture by increasing doses of $E_{2}, E_{2}$ and DES. The values are means of triplicates and bars are standard deviations. The control value is $5 \mathrm{ng} / \mathrm{ml}$. 


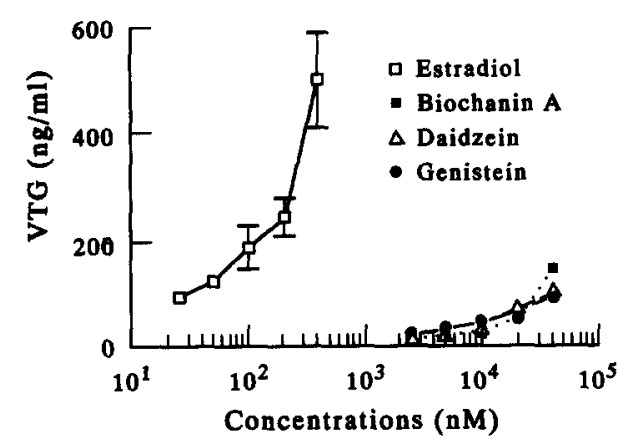

Fig. 6. Stimulation of hepatocytes in culture by increasing doses of $E_{2}$, biochanin $A$, daidzein and genistein. All the values are means of triplicates. The bars for $E_{2}$ are standard deviations. For the phytoestrogens error bars were ommited for clarity. The control value is $3.8 \mathrm{ng} / \mathrm{ml}$.

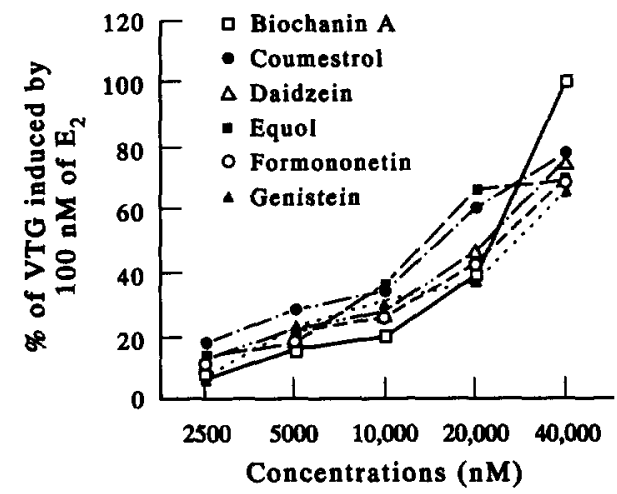

Fig. 7. Stimulation of hepatocytes in cultures by increasing doses of the phytoestrogens biochanin $\mathrm{A}$, coumestrol, daidzein, equol, formononetin and genistein. The production of VTG is expressed as the percentage of VTG induced by $100 \mathrm{nM}$ of $E_{2}$ in the corresponding culture because the results have been obtained from two different cultures in which the number of cells was slightly different. The value are means of triplicates. Error bars were omitted for clarity. a health criteria and a required function [18-20]. In fish and especially in rainbow trout the field is hardly explored and except work by Dr Vaillant [21] few metabolic activities in hepatocyte culture have been clearly demonstrated. In oviparous animals, the synthesis of VTG by hepatocytes represent a good system with which to study the mechanism of action of steroid hormones [31-34]. Most of these studies have used hepatocytes of either amphibians (especially Xenopus laevis) or birds (especially chickens), though some have been based on hepatocytes from fish $[24,35-37]$. Various techniques have been used to culture fish hepatocytes $[35,37]$. We chose to use the system first developed by Flouriot and Valotaire [38] and modified by Foucher et al. [39], in which gentle shaking is used to encourage the hepatocyte to form small aggregates, as a first step towards tissue organization [40]. In our system, the cells are kept for 10 to 12 days (see Fig. 1) in what appear to be good physiological conditions (if one considers their ability to respond to $\mathrm{E}_{2}$ stimulation represents a measure of good health). It is also interesting to note that the cells were cultured in a minimum medium without any supplements such as serum [41] or thyroid hormones [42] which have been claimed to be indispensable for hepatocyte maintenance in culture as well as for VTG production in both fish [42] and amphibian [43]. This is important because the addition of serum, for example, will introduce many different compounds, some of which (such as growth factors) are likely to modify the response to the primary stimulation

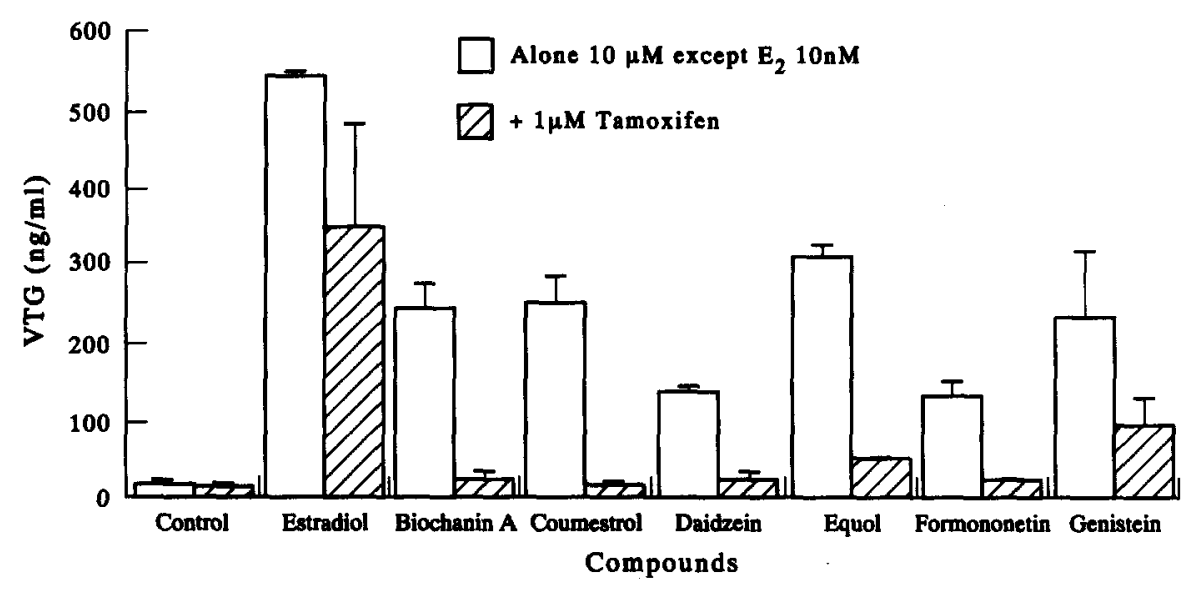

Fig. 8. Effect of tamoxifen $(1 \mu \mathrm{M})$ on VTG production by cultured hepatocytes in the presence of different phytoestrogens (all at $10 \mu \mathrm{M}$ ). All values are the mean of a triplicate $\pm \mathrm{SD}$. $\mathrm{E}_{2}$ was employed at $10 \mathrm{mM}$. In all cases (except control) tamoxifen significantly decreased the production of VTG $(P<0.01)$ according to a non-parametric analysis. The control value is $2.3 \mathrm{ng} / \mathrm{ml}$ 
by the hormone itself. In addition to the use of minimum medium, we used a 'phenol red-free' medium, since phenol red has been shown to be weakly estrogenic $[44,45]$.

In Fig. 2 the production of VTG by the hepatocytes is shown to be related to the $E_{2}$ concentration and exhibits a sigmoidal pattern which is in accordance with the receptor-mediated action of $E_{2}$ on VTG synthesis [46, 47]. As far as we know, $E_{2}$ binds to a receptor whose location within the cell is not yet completely clear, at least in fish $[6,7,48,49]$. The $E_{2}$ receptor complex then binds to the DNA, enhancing protein transcription $[6,7]$. The action of $E_{2}$ is thus dependant upon the number of $E_{2}$ receptors available. It has been recently demonstrated in trout that, as in mammals or amphibians [50,51], the receptor itself is induced by $E_{2}[46,47]$. Thus the kinetics of transcription of both the $E_{2}$ receptor and the VTG genes, together with the stability of the mRNA for VTG [52], the turn over of the $E_{2}$ receptor, the $E_{2}$ metabolism in culture and the rate of exocytosis of VTG, will all play a part in determining the rate of secretion of VTG into the medium.

The results obtained with androgens and progestagens (Fig. 2) agree with various studies demonstrating the low estrogenic action of these compounds in vivo [53-55]. The potencies of these steroids are very low indeed and they are unlikely to have the same effect in natural conditions, since the doses required to induce an effect are far higher than the physiological concentrations circulating in plasma [56]. According to some studies, the effects of some androgens, such as testosterone for instance, is related to their ability to be transformed into estrogens by specific enzymes such as aromatase [54]. However, 11-ketotestosterone is considered not to be aromatizable. Thus, although the possibility of the transformation of 11-ketotestosterone and/or progestagens into estrogens cannot be unequivocally rejected, it seems more likely that at high concentrations these steroids can bind to the $E_{2}$ receptor. This theory is supported by the results obtained using tamoxifen simultaneously with androgens and progestagens. In all three cases, tamoxifen inhibited totally the action of these steroids. Since tamoxifen is known to compete with estrogen for binding to the $E_{2}$ receptor [57], these results indicate that the activity of these steroids is mediated via this receptor. The control treated only with tamoxifen showed no response of the hepatocytes in terms of VTG production. This allows us to consider the action of tamoxifen as purely antagonistic in the system we use despite the fact that other studies demonstrated that tamoxifen action is quite complex since this drug can interact on more than one binding site and can be both agonist and antagonist of $E_{2}$ on cell growth [58, 59]. It should be noted that the inhibition, of the 'estrogenic activity' of both androgens and progestagens by tamoxifen appears to be a real inhibition, rather than a toxic effect of tamoxifen. This is demonstrated clearly by the failure of tamoxifen (at the dose used) to totaly block the production of VTG in the presence of $E_{2}$ (see Fig. 3).

The two $\mathrm{E}_{2}$ conjugated derivatives, $\mathrm{E}_{2} \mathrm{SO}_{4}$ and $E_{2}$ gluc, were both quite potent; the former seemed to be as potent as $E_{2}$ itself and the latter $40 \pm 14$ times less potent. The action of these compounds can probably be explained by hydrolysis of the conjugates by the hepatocytes, since according to many studies dealing with the structure-activity relationships of estrogens, it has been demonstrated that the hydroxyl groups in the 3 and $17 \beta$ positions are crucial in the recognition steps between the hormone and its receptor [60]. Here we choose to test two $E_{2}$ derivatives in which one of these crucial hydroxyl groups was hidden by a bigger stereochemical group. If no metabolism had occurred, the binding to the receptor would presumably have been prevented. Up to very recently these steroid derivatives were, in general, considered as physiologically inactive. However, a study published a few years ago [61] has already pointed out the importance of $\mathrm{E}_{2} \mathrm{SO}_{4}$ in breast cancer cells. It reported the presence of sulfatase for the $\mathrm{C}_{3}$ in many types of tissue. These results might be of great interest since in many species, including fish species and human, the concentrations of the sulfate and/or glucoside derivatives can be very high, sometimes 10 times higher than the free compounds $[62,63]$. According to our results it appears that the liver, which has been demonstrated to be responsible for the sulfo- and gluco-conjugation of many compounds in fish [64], including steroids, is also able to hydrolyze them, probably due to the presence in the hepatocytes of sulfatase or glucuronidase.

The results presented in Fig. 5 show the estrogenic potency of two widely-used synthetic estrogens. According to these results, $\mathrm{EE}_{2}$ is as potent as $E_{2}$ and DES is about half as potent. 
These figures are in disagreement with other previous results obtained in vivo showing, for instance, that $\mathrm{EE}_{2}$ was up to 10 times more potent than $E_{2}$ [65]. This strong effect in vivo is explained by a slower metabolism of $E_{2}$ when compared to $E_{2}$. It is likely that the ethynyl group, located on the 17th carbon in the $a 1$ position, prevents the sulfo- and/or gluco-conjugation of the molecule via its $17 \beta$ hydroxyl group [65]. Then $\mathrm{EE}_{2}$ is not eliminated as fast as $E_{2}$ and thus remains longer in the blood.

We observed that all six phytoestrogens tested possessed estrogenic activity in the hepatocyte culture system. All these compounds appeared to have more or less the same potency, ranging between 1000 and 2000 times less potent than $E_{2}$. These results are in agreement with results previously published by many authors working on these compounds $[66,67]$ which attribute to equol and coumestrol a potency about 1000 times less than that of $E_{2}$. However, according to the previous literature the estrogenic action of the isoflavones (including biochanin A, genistein, formonetin and daidzein) varies from one compound to another and from one study to another, suggesting inter-specific differences from one animal model to another [68] and/or technical differences in the systems used to assess the activities of these chemicals (in vivo tests [67]; in vitro tests [68]). However, it is important to note that when these compounds were tested in vivo in sturgeon, their activity did seem to be variable [27].

In addition, it is interesting to note that in our system the phytoestrogens do not seem to be more potent than androgens and progestagens. Very high concentrations of phytoestrogens can be present in some vegetables $[69,70]$ which, when eaten, can produce estrogenic effects. Hence the phytoestrogens have been considered weakly estrogenic. They were also estrogenic in our hepatocyte cultures, but no more than androgens and progestagens. The results presented in Fig. 7, where the action of tamoxifen on the induction of VTG by phytoestrogens in shown, demonstrate undoubtedly an interaction of these compounds with the $E_{2}$ receptors as already reported in other species $[68,71]$.

In summary, this study reports the use of a new biological test for estrogenicity which possesses the advantage of allowing at least some of the metabolic activities which normally take place in vivo. We think that this technique could be of interest for the measurement of the relative potency of chemicals whose estrogenicity is only revealed after hepatic metabolism. Of course the results presented here still cannot be directly extrapolated to the in vivo situation, but at least the technique is likely to provide complementary results when one speaks about in vitro estrogenicity. Many compounds would be worth testing in this system, including xenobiotics from human industrial wastes such as p-nonyl-phenol, metoxyclor, kepone or DDT which are known to possess estrogenic activity in other systems $[1,2,72]$ as well as conjugated derivatives from endogenous or exogenous origin, since these compounds are usually present in much higher concentrations than their corresponding native forms.

Acknowledgements - This work was funded by two one year research grants (contract Nos 3250 and 5024) which were awarded to Drs Pelissero and Sumpter by the European Economic Community.

\section{REFERENCES}

1. McLachlan J. A.: Estrogens in the Environment (Edited by J. A. Mc Lachlan). Elsevier, North Holland (1980).

2. McLachlan J. A.: Estrogens in the Environment II (Edited by J. A. McLachlan). Elsevier, New York (1985).

3. Hertz R.: The estrogen problem. Retrospect and prospect. In Estrogens in the Environment. II (Edited by J. A. McLachlan) Elsevier, New York (1985) pp. 1-11.

4. Stob M.: Naturally occurring food toxicants: estrogens. In Handbook of Naturally Occurring Food Toxicants (Edited by M. Rechcigl Jr). CRC Press, FL (1983) pp. 80-100.

5. McLachlan J. A., Korach K. S., Newbold R. R. and Degen G. H.: Diethylstilboestrol and other oestrogens in the environment. Fund. Appl. Toxic 4 (1984) 646-691.

6. Gorsky J.: Models of estrogenic hormone action. In Estrogens in the Environment. (Edited by J. A. McLachlan). Elsevier, North Holland (1980) pp. 3-9.

7. Green S.: Modulation of oestrogen receptor activity by oestrogens and anti-oestrogens. J. Steroid Biochem. Molec. Biol. 37 (1990) 747-751.

8. Metzler M.: Role of metabolism in determination of hormonal activity of estrogens: introductory remarks. In Estrogens in the Environment. II (Edited by J. A. McLachlan). Elsevier, New York (1985) pp. 187-189.

9. Katzenellenbogen J. A., Katzenellenbogen B. S., Tatee T., Robertson D. W. and Landvatter S. W.: The chemistry of estrogens and antiestrogens: relationships between structure, receptor binding and biological activity. In Estrogens in the Environment (Edited by J. A. McLachlan). Elsevier, North Holland (1980) pp. 33-51.

10. Raynaud J. P., Ojasoo T., Bouton M. M., Bignon E., Pons $M$. and Crastes de Paulet A.: Structure-activity relationships of steroid estrogens. In Estrogens in the Environment. II (Edited by J. A. McLachlan). Elsevier, New York (1985) pp. $24-42$.

11. Duax W. L. and Griffin J. F.: Structure-activity relationships of estrogenic chemicals In Estrogens in the Environment. II (Edited by J. A. McLachlan). Elsevier, New York (1985) pp. 15-23. 
12. Braden A. W. H., Hart N. K. and Lamberton J. A.: The oestrogenic activity and metabolism of certain isoflavones in sheep. Aust. J. Agric. Res. 18 (1967) 335-348.

13. Tang B. Y. and Adams N. R.: Effect of equol on oestrogen receptors and on synthesis of DNA and protein in the immature rat uterus. J. Endocr. 85 (1980) 291-297.

14. Welshons W. V., Murphy C. S., Koch R., Calaf G. and Jordan V. C.: Stimulation of breast cancer cells in vitro by the environmental estrogen enterolactone and the phytoestrogen equol. Breast Cancer Res. Treat. 10 (1987) 169-175.

15. Horwitz K. B. and Mc Guire W. L.: Estrogen control of progesterone receptor in human breast cancer: correlation with nuclear processing of estrogen receptor. J. Biol. Chem. 253 (1978) 2223-2228.

16. Jordan V. C., Koch R. and Bain R. R.: Prolactin synthesis by cultured rat pituitary cells: an assay to study estrogens, antiestrogens and their metabolites in vitro In Estrogens in the Environment II (Edited by J. A. McLachlan). Elsevier, New York (1985) pp. 221-237.

17. Maitre J. L., Valotaire Y. and Gueguen-Guillouzo C.: Estradiol-17 $\beta$ stimulation of vitellogenin synthesis in primary culture of male rainbow trout hepatocytes. In vitro Cell. Dev. Biol. 22 (1986) 337-343.

18. Wu D. F., Clejan L., Potter B. and Cederbaum A. I.: Rapid decrease of cytochrome $P$-450IIEI in primary hepatocyte culture and its maintenance by added 4methylpyrazole. Hepatology 12 (1990) 1379-1389.

19. Inoue C., Yamamoto H., Nakamura T., Ichihara A. and Okamoto $H$. Nicotinamide prolongs survival of primary cultured hepatocytes without involving loss of hepatocyte-specific functions. J. Biol. Chem. 264 4747-4750.

20. Guyomard C., Chesne C., Meunier B., Fautrel A., Clerc C., Morel F., Rissel M., Campion J.-P. and Guillouzo A.: Primary culture of adult rat hepatocytes after 48-hour preservation of the liver with cold UW solution. Hepatology 12 (1990) 1329-1336.

21. Vaillant C.: Hépatocytes de truite en culture: un modèle pour l'étude de la synthèse de la vitellogénine et des activités de biotransformation. Thesis of Rennes University No 223 (May 1988) 107p.

22. Hansson T. and Gustafsson J. A.: Sex differences in the hepatic metabolism of 4-androstene-3, 17-dione in rainbow trout, Salmo gairdnerii. Gen. Comp. Endocr. 44 (1981) 181-188.

23. Hansson T. and Gustafsson J. A.: In vitro metabolism of 4-androstene-3, 17-dione by hepatic microsomes from the rainbow trout (Salmo gairdnerii): effects of hypophysectomy and oestradiol 17\% J. Endocr. 90 (1981) 103-112.

24. Wallace $\mathbf{R}$. A.: Oocyte growth in non-mammalian vertebrates. In The Vertebrate Ovary (Edited by R. E. Jones). Plenum Press, New York (1989) pp. 469-502.

25. Tyler C.: Vitellogenesis in salmonids. In Reproductive Physiology of Fish. (Edited by A. P. Scott, J. P. Sumpter, D. A. Kime and M. S. Rolfe). Fish Symp. 91 Sheffield (1991) pp. 297-301

26. $\mathrm{Ng}$ T. B. and Idler $\mathrm{D}$. R.: Yolk formation and differentiation in teleost fishes. In Fish Physiology IX (Edited by W. S. Hoar, D. J. Randall and E. M. Donaldson). Academic Press, New York (1983) pp. 373-404.

27. Pelissero, C., Bennetau, B., Babin, P., Le Menn, F. and Dunoguès J.: The estrogenic activity of certain phytoestrogens in the Siberian sturgeon Acipenser baeri. J. Steroid Biochem. Molec. Biol. 38 (1991) 292-299.

28. Sumpter J. P.: The purification, radioimmunoassay and plasma levels of vitellogenin from the rainbow trout Salmo gairdneri. In Trends in Comparative Endocrinology (Edited by B. Lofts and W. H. Holmes). Hong Kong University Press, Hong Kong (1985) pp. $355-357$
29. Copeland P. A., Sumpter J. P., Walker T. K. and Croft M.: Vitellogenin levels in male and female rainbow trout Salmo gairdneri at various stages of the reproductive cycle. Comp. Biochem. Physiol. 83B (1986) 487-498.

30. Scherer B.: Biostatistique (Edited by G. Morin). Boucherville, Quebec, Canada (1984) 850 p.

31. Wang L. J. and Knowland J.: Synthesis of vitellogenin in culture of male and female frog liver regulated by estradiol treatment in vitro. Proc. Natn. Acad. Sci. U.S.A. 72 (1975) 3172-3175.

32. Liang $H$. and Jost J. P.: An estrogen-dependent polysomal protein binds to the $5^{\prime}$ untranslated region of the chicken vitellogenin mRNA. Nucleic Acids Res. 19 (1991) 2289-2294.

33. Seal S. N., Davis D. L. and Burch J. B. E.: Mutational studies reveal a complex set of positive and negative control elements within the chicken vitellogenin II promoter. Molec. Cell. Biol. 11 (1991) 2704-2717.

34. McEwan I. J., Saluz H. P. and Jost J. P.: In vivo and in vitro protein-DNA interactions at the distal oestrogen response element of the chicken vitellogenin gene: evidence for the same protein binding to this sequence in hen and rooster liver. J. Steroid Biochem. Molec. Biol. 38 (1991) 27S-283.

35. Kocal T., Quinn B. A., Smith I. R., Ferguson H. W. and Hayes M. A.: Use of trout serum to prepare primary attached monolayer cultures of hepatocytes from rainbow trout (Salmo gairdneri). In vitro Cell. Dev. Biol. 24 (1988) 304-308.

36. Stanchfield J. E. and Yager J. D.: Primary induction of vitellogenin synthesis in monolayer cultures of amphibian hepatocytes. J. Cell Biol. 84 (1980) 468-475.

37. Vaillant C., Le Guellec C., Pakdel F. and Valotaire $Y$. Vitellogenin gene expression in primary culture of male rainbow trout hepatocytes. Gen. Comp. Endocr. 70 (1988) 284-290.

38. Flouriot G., Salbert G., Le Menn F., Pelissero C. and Valotaire $Y$.: Estrogen receptors gene expression and regulation in the liver of the rainbow trout. Proceedings of the Third International Congres of Comparative Physiology and Biochemistry. Tokyo, Japan, August 25-30 (1991) In press.

39. Foucher J. L., Niu P. D., Mourot B. and Le Gac F.: In vivo and in vitro studies on SBP regulation in rainbow trout (Oncorhynchus mykiss): influence of sex steroid hormones and of factors linked to growth and metabolism. J. Steroid Biochem. Molec. Biol. 39 (1991) 345-352.

40. Blair J. S., Miller M. R., Pack D., Barnes R., Teh S. J. and Hinton D. E.: Isolated trout liver cells: exhibiting cell to cell interactions. In Vitro Cell Dev. Biol. 26 (1990) 237-249.

41. Watanabe T., Nakano M., Asakawa H. and Morimoto T.: Cell culture of rainbow trout liver. Nippon Suisan Gakk. 53 (1987) 537-542.

42. Bhattacharya S., Plisetkaya E., Dickhoff W. W. and Gorbman A.: The effects of estradiol and triodothyronine on protein synthesis by hepatocytes of juvenile coho salmon (Oncorhynchus kisutch). Gen. Comp. Endocr. 57 (1985) 103-109.

43. Kawahara A., Kohara S. and Amano M.: Thyroid hormone directly induces hepatocyte competence for estrogen-dependant vitellogenin synthesis during the metamorphosis of Xenopus laevis. Dev. Biol. 132 (1989) 73-80.

44. Dumesic D. A., Renk M. and Kamel F.: Estrogenic effects of phenol red on rat pituitary cell responsiveness to gonadotropin-releasing hormone. Life Sci. 44 (1989) $307-406$.

45. Ortmann O., Sturm R., Knuppen R. and Emons G.: Weak estrogenic activity of phenol red in the pituitary gonadotroph: re-evaluation of estrogen and antiestrogen effects. J. Steroid Biochem. 35 (1990) 17-22. 
46. Mommsen T. P. and Lazier C. B.: Stimulation of estrogen receptor accumulation by estradiol in primary cultures of salmon hepatocytes. FEBS Lett. 195 (1986) 269-271.

47. Pakdel F., Féon S., Le Gac F., Le Menn F. and Valotaire $Y_{\text {.: }}$ In vivo estrogen induction of hepatic estrogen receptor mRNA and correlation with vitellogenin mRNA in rainbow trout. Molec. Cell. Endocr. 75 (1991) 205-212.

48. Turner R. T., Dickhoff W. W. and Gorbman A.: Estrogen binding to hepatic nuclei of pacific hagfish Eptatretus stouti. Gen. Comp. Endocr. 45 (1981) 26-29.

49. Sloop T. C., Sherman B. and Lucier G. W.: Characterization of a cytosolic steroid-binding protein in the liver of the winter flounder, Pseudopleuronectes americanus. Gen. Comp. Endocr. 55 (1984) 157-162.

50. Green S. and Chambon P.: A superfamily of potentially oncogenic hormone receptors. Nature 324 (1986) 615-617.

51. Riegel A. T., Aitken S. C., Martin M. B. and Schoenberg D. R.: Differential induction of hepatic estrogen receptor and vitellogenin gene transcription in Xenopus laevis. Endocrinology 120 (1987) 1283-1290.

52. Mc Kenzie E. A. and Knowland J.: High concentrations of estrogen stabilize vitellogenin mRNA against cytoplasmic degradation but physiological concentrations do not. Molec. Endocr. 4 (1990) 807-811.

53. Hori S. H., Kodama T. and Tanahashi K.: Induction of vitellogenin synthesis in goldfish by massive doses of androgens. Gen. Comp. Endocr. 37 (1979) 306-320.

54. Le Menn F.: Some aspect of vitellogenesis in a teleostean fish: Gobius niger L. Comp. Biochem. Physiol. 62B (1979) 495-500.

55. Bromage N. R. and Cumaranatunga R.: Egg production in the rainbow trout. In Recent Advances in Aquaculture vol III (Edited by J. F. Muir and R. J. Roberts). Croom Helm, London (1988) pp. 65-138.

56. Scott A. P. and Sumpter J. P.: A comparison of the female reproductive cycles of autumn-spawning and winter-spawning strains of rainbow trout (Salmo gairdneri Richardson). Gen. Comp. Endocr. 52 (1983) 79-85.

57. Sutherland R. L. and Murphy, L. C.: Mechanism of oestrogen antagonism by nonsteroidal antiestrogens. Molec. Cell. Endocr. 25 (1982) 5-23.

58. Sutherland R. L., Green M. D., Hall R. E., Reddel R. R. and Taylor I. W.: Tamoxifen induces accumulation of MCF-7 human mammary carcinoma cells in the Go/G1 phase of the cell cycle. Eur. J. Cancer. Clin. Oncol. 19 (1983) 615-621.

59. Sudo K., Monsma F. J. and Katsenellenbogen B. S.: Antiestrogen binding sites distinct from the estrogen receptor: subcellular localisation ligand specificity and distribution in tissues of the rat. Endocrinology 112 (1983) 425-434.

60. Duax W. L. and Week C. M.: Molecular basis of estrogenicity: X-ray crystallographic studies. In Estrogens in the Environment (Edited by J. A. McLachlan). Elsevier, North Holland (1980) pp. 11-31.

61. Pasqualini J. R., Gelly C., Nguyen B. L. and Vella C.: Importance of estrogen sulfates in breast cancer. J. Steroid Biochem. 34 (1989) 155-163.

62. Honjo H. Kitawaki J., Itoh M., Yasuda J., Iwasaku K., Urabe M., Naitoh K., Yamamoto T., Okada H., Ohkubo T. and Nambara T.: Serum and urinary estrone sulfate during the menstrual cycle, measured by a direct radioimmunoassay and fate of exogenously injected estrone sulfate. Horm. Res. 27 (1987) 61-68.

63. Scott A. P. and Canario A. V. M.: 17a dihydroxy-4 pregen-3-one 20 sulfate: a major new metabolite of the teleost oocyte maturation-inducing steroid. Gen. Comp. Endocr. 85 (1992) 91-100.

64. James M. O.: Xenobiotic conjugation in fish and other aquatic species. In Xenobiotic Conjugation Chemistry (Edited by G. D. Paulson, J. Caldwell, D. H. Hutson and J. J. Menn). Am. Chem. Soc., New York (1986) pp. 29-47.

65. Thomas J. A. and Keenan E. J.: Principles of Endocrine Pharmacology (Edited by J. A. Thomas and E. J. Keenan). Plenum Medical Book Co, New York (1986) $624 \mathrm{p}$.

66. Wong E. and Flux D. S.: Oestrogenic activity of red clover isoflavones and some of their degradation products. J. Endocr. 24 (1962) 341-348.

67. Kasiro R., Kennedy J. P., Cole E. R. and SouthwellKeely P. T.: The oestrogenicity of equol in sheep. J. Endocr. 103 (1984) 395-399.

68. Shutt D. A. and Cox R. I.: Steroid and phytoestrogen binding to sheep uterine receptors in vitro. J. Endocr. 52 (1972) 299-310.

69. Knuckles B. E., de Fremery D. and Kohler G. O.: Coumestrol content of fractions obtained during wet processing of alfalfa. J. Agric. Food Chem. 24 (1976) $1177-1180$.

70. Setchell K. D. R.: Naturally occurring non-steroidal estrogens of dietary origin. In Estrogens in the Environment (Edited by J. A. McLachlan). Elsevier, New York (1985) pp. 69-87.

71. Shemesh M., Lindner H. R. and Ayalon N.: Affinity of rabbit uterine receptor for phytooestrogens and its use in a competitive protein-binding radioassay for plasma coumestrol. J. Reprod. Fert. 29 (1972) 1-9.

72. Soto A. M., Justicia H., Wray J. W. and Sonnenschein C.: $p$-Nonyl-phenol: an estrogenic xenobiotic released from "Modified" polystyrene. Environ. Health Persp. 92 (1991) 167-173. 